\title{
Progression of Internet Banking System in Bangladesh and its Challenges
}

\author{
Bipasha Sarker \\ Assistant Keeper \\ (Assistant Director) \\ Department of Currency \\ Management \\ Bangladesh Bank \\ Dhaka, Bangladesh
}

\author{
Bidisha Sarker \\ Department of Finance \\ University of Dhaka \\ Dhaka 1000 \\ Bangladesh.
}

\author{
Prajoy Podder \\ Institute of ICT \\ Bangladesh University of \\ Engineering and \\ Technology \\ Dhaka, Bangladesh
}

\author{
Md Robiul Alam \\ Robel \\ Department of CSE \\ Cumilla University
}

\begin{abstract}
Internet banking has become a hotcake in the arena of digital banking. Internet banking is modern technology based computerized system that provides one of the easiest banking systems to client with low cost and quick services. Internet Banking" refers to systems that enable bank customers to access accounts and general information on bank products and services through a personal computer (PC) or other intelligent devices. Numerous factors including competitive cost, customer service, and demographic considerations are motivating banks to evaluate their technology and assess their electronic commerce and Internet banking strategies. As of January 2018, there are approximately 17.61 lakh users of internet banking. Most of the users adopt internet banking for fund transfer operation. About 7.18 lakh transactions including 2,175 crore Taka were performed through the internet banking platform in January 2018 according to the statistical report of Bangladesh Bank. Taking into consideration the necessity of internet banking, this study has been conducted. This paper mainly focuses on the internet banking configuration, operations and banker's appreciation of using internet banking. This paper also focuses some ramifications of cyber threats in order to establish secure internet banking because they are the main pitfalls in order to establish trustworthy effortless internet banking system.
\end{abstract}

\section{Keywords}

Internet Banking, ATM, BEFTN, RTGS, Cyber Security.

\section{INTRODUCTION}

The era of Internet came in Bangladesh, after the beginning of UUCP e-mail in 1993 as well as establishing IP connectivity in 1996 [1]. By July 1997 there were an estimated 5,500 IP and UUCP accounts [2] in the country and by the end of 2000 it has been forecasted that the account holder could reach more than 50,000 through different Internet Service Providers (ISP), who are proposing Internet services with bandwidth ranging between $65 \mathrm{Kbps}$ and $2 \mathrm{Mbps}$ through VSAT, Broadband.

Though internet came in Bangladesh in 1996 but the usage of internet in banking sector started in begin after the year 2000 . Internet Banking is gaining popularity in this upcoming digital Bangladesh. A number of private and state owned commercial banks have become online now based on the demand and requirement of fast banking. Not only banking facility is not provided by Internet banking but also international economy has become widespread. According to a report of BIBM, spending 1 taka in internet and ICT based banking will make it equal productivity of 136 taka for the bank. On the contrary, spending 1 taka in traditional banking without the touch of internet band ICT will make it equal productivity of 58 taka for the bank. The average profit in banking sector was about 555 crore taka in 2000 . In 2015, the average profit has become 16 times higher (about 8500 crore taka) [3-5].

Internet Banking is one of the few web applications where benefits to customers and banks are already widely proven. "Internet Banking" refers to systems that enable bank customers to access accounts and general information on bank products and services through a desktop or laptop or mobile phone or other intelligent devices. Internet banking means a kind of self-help financial services provided by the bank for its clients by the medium of Internet, including account information inquiry, account transfer \& payment, online payment, agency services, etc.

The first commercial bank that launched internet banking in Bangladesh is Standard Chartered Bank. But now many banks have launched Internet Banking in Bangladesh. Amongst those HSBC, City Bank, BRAC Bank, Bank Asia, Southeast Bank, AB Bank, Eastern Bank Limited, Mercantile Bank, Premier Bank etc are in action already. Some of them are known as online banking, some of them are known as Internet Banking, offering numerous facilities. Like City Bank has the facility of account check and statement print including query about cheque book information. The Top 5 popular internet banking apps in recent days are illustrated below:

1. City touch (established by City Bank)

2. EBL Sky Banking (established by Eastern Bank Limited)

3. MTB Smart Banking (established by Mutual Trust Bank)

4. SC Mobile Banking (launched by Standard Chartered Bank)

5. Brac Bank Mobile (launched by Brac bank)

\section{OBJECTIVES OF THE STUDY}

All The primary objective of this work plans to fill up the gap in research in internet and online based banking for the identification of the bankers' opinion in Bangladesh. The objectives are given below:

a) To evaluate internet banking system in Bangladesh

b) To know the progress of internet banking from 2014 to till now 
c) To familiarize with other recent internet banking based systems such as BEFTN, NPSB

d) To consider bankers' opinion on adoption of internet banking and the problems faced during the running time.

\section{ELECTRONIC BANKING SERVICES IN BANGLADESH}

Banking sector has been relishing different cutting edge electronic banking solutions. These solutions can enable a bank in order to share banking information as well as transaction details electronically. There are different aspects of electronic banking such as internet banking, online banking, online payment etc [6]. In Bangladesh, 56 banks out of 58 had at least one online branch. There were 41 banks as of end-December 2018 that provide internet banking service. According to the data of Sustainable Finance Department of Bangladesh Bank, 3,687 branches of State owned commercial banks (SCBs) out of 3713 and 5059 branches of private commercial banks (PCBs) out of 5060 provide online banking coverage till December 2018.

From the table 1, it can be declared that the adoption of electronic banking services such as internet banking, credit card, debit card by the commercial banks is increasing almost in each year. In 2013, there were 27 banks that launched internet banking on the contrary there were 46 banks in 2018 that launched internet banking. Till 2018, the number of banks provided debit and credit card facility is 53 and 39 respectively.

Table 1: Number of Banks Providing Electronic Banking Services (Source: Financial Stability Report (2013-2018), Bangladesh Bank)

\begin{tabular}{|cccc|}
\hline Year & $\begin{array}{c}\text { Internet } \\
\text { Banking }\end{array}$ & Debit Card & Credit Card \\
\hline 2013 & 27 & 41 & 28 \\
\hline 2014 & 27 & 41 & 28 \\
\hline 2015 & 30 & 50 & 34 \\
\hline 2016 & & & \\
\hline 2017 & 36 & 50 & 37 \\
& 41 & 53 & 37 \\
\hline 2018 & 46 & 53 & 39 \\
\hline & & & \\
\hline & & 5 & \\
\hline
\end{tabular}

\section{Number of Banks Providing Electronic Banking}

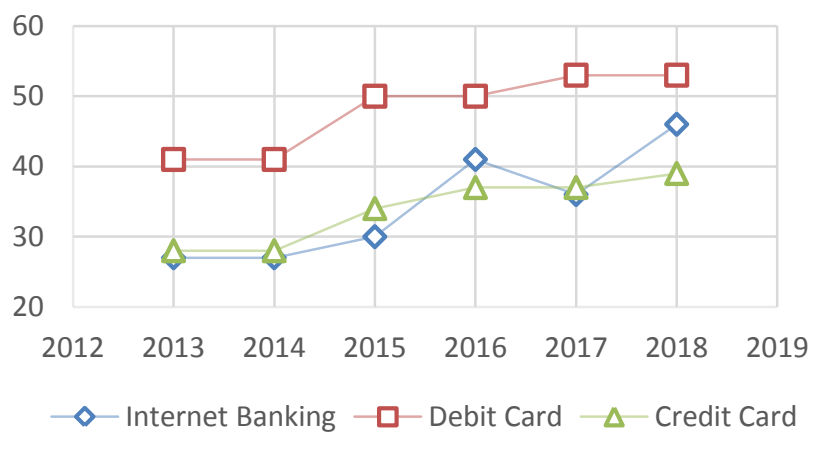

Fig 1: Evolution of Electronic Banking from 2013-2018

From the table 2, it can be illustrated that there the highest amount of taka (approximately 365 billion taka) had been transacted in 2017 using internet banking. There is a little decrease in 2018 (about 325 billion taka). The highest amount of taka (1385.3 billion taka) had been transacted in 2018 using ATM channel where in Debit Card 1420.8 billion taka had been successfully transacted in 2018. It can be clearly stated that the popularity of internet banking is increasing day by day.

Table 2: Volume of E-Banking (Electronic Banking) Transactions (in Billion Bangladeshi Taka) (Source: Statistics Department, Bangladesh Bank)

\begin{tabular}{|cccc|}
\hline Year & ATM & Debit Card & $\begin{array}{c}\text { Internet } \\
\text { Banking }\end{array}$ \\
\hline 2013 & 654.3 & 775.7 & 90.5 \\
\hline 2014 & 685.9 & 805.9 & 217.3 \\
\hline 2015 & 914.2 & 960.9 & 247.6 \\
\hline 2016 & 1107.3 & 1179 & 308 \\
\hline 2017 & 1194.7 & 1239.5 & 365 \\
\hline 2018 & 1385.3 & 1420.8 & 325 \\
\hline
\end{tabular}




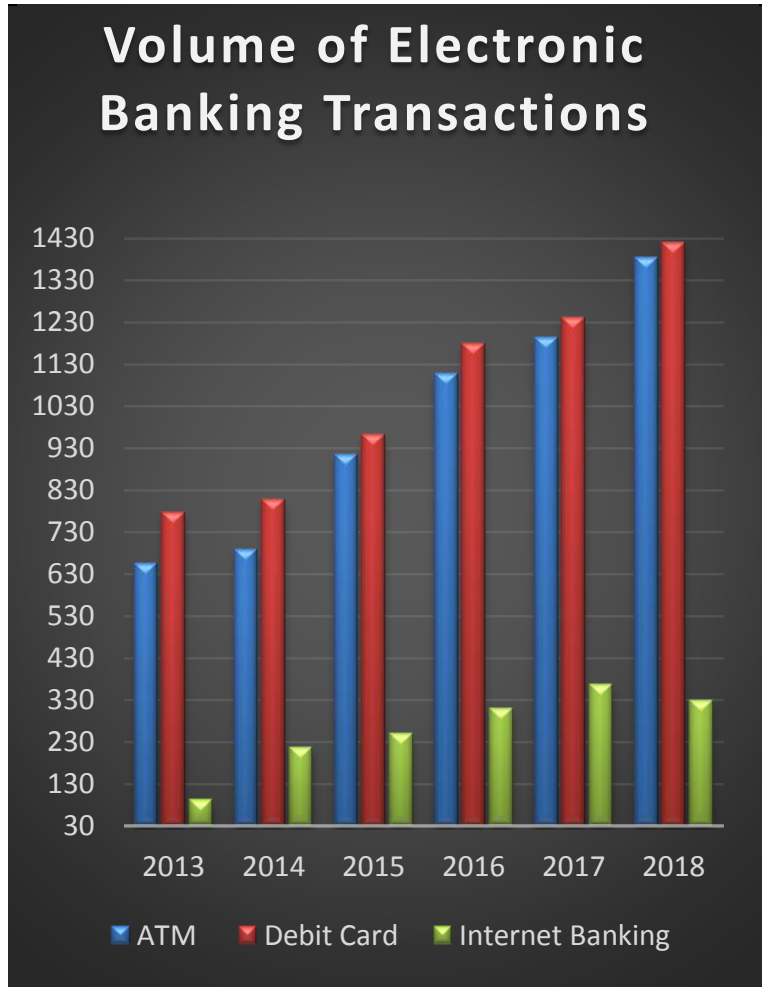

Fig 2: Volume of transactions using ATM, Debit and Internet Banking from 2013-2018

Figure 2 illustrates the Volume of transactions using ATM, Debit and Internet Banking from 2013-2018. There is a sharp increase of transaction with the increased year.

\section{TRANSACTION TRENDS OF INTERNET BANKING IN 2018-2019:}

From the table 3, it can be showed that 2,264 times internet banking fund transfer successfully accomplished in January 2018 where in June 2018, the number of Internet banking fund transfer operation was 6,427. On the contrary, 20, 985 transactions successfully completed in December 2018 using internet banking channel. The transferred amount in taka was 43,374,035.78 in January 2018 where the transferred amount in taka was 426,206,625.50 in December 2018. The largest percent change in Fund Transfer (Taka) from one month to another month was 45.95\% (November-December, 2018). Figure 3 is a graphical representation of monthly transaction Rate in 2018.

Table 3: Monthly Transaction Trends in the year 2018 in Internet Banking System (Source: Bangladesh Bank)

\begin{tabular}{|c|c|c|c|}
\hline Month & $\begin{array}{l}\text { Internet } \\
\text { Banking } \\
\text { Fund } \\
\text { Transfer } \\
\text { (Amount) }\end{array}$ & $\begin{array}{c}\text { Internet } \\
\text { Banking Fund } \\
\text { Transfer (Taka) }\end{array}$ & $\begin{array}{l}\text { \% Change } \\
\text { in Fund } \\
\text { Transfer } \\
\text { (Taka) } \\
\text { from one } \\
\text { month to } \\
\text { another } \\
\text { month }\end{array}$ \\
\hline January & 2,264 & $43,374,035.78$ & \multirow[t]{2}{*}{$11.9 \%$} \\
\hline February & 2,454 & $48,534,007.35$ & \\
\hline March & 2,706 & $45,164,212.85$ & \multirow[t]{2}{*}{$46.55 \%$} \\
\hline April & 3,728 & $66,188,085.25$ & \\
\hline
\end{tabular}

\begin{tabular}{|c|c|c|c|}
\hline May & 5,144 & $88,833,490.31$ & \multirow{2}{*}{$26.26 \%$} \\
\cline { 1 - 3 } June & 6,427 & $112,163,542.98$ & \\
\hline July & 8,348 & $145,072,770.49$ & \multirow{2}{*}{$37.69 \%$} \\
\cline { 1 - 3 } August & 10,494 & $199,754,326.02$ & \\
\hline September & 11,373 & $210,404,303.13$ & \multirow{2}{*}{$30.84 \%$} \\
\cline { 1 - 3 } October & 14,458 & $275,286,032.71$ & \\
\hline November & 15,338 & $292,019,129.90$ & \multirow{2}{*}{$45.95 \%$} \\
\cline { 1 - 3 } December & 20,985 & $426,206,625.50$ & \\
\hline
\end{tabular}

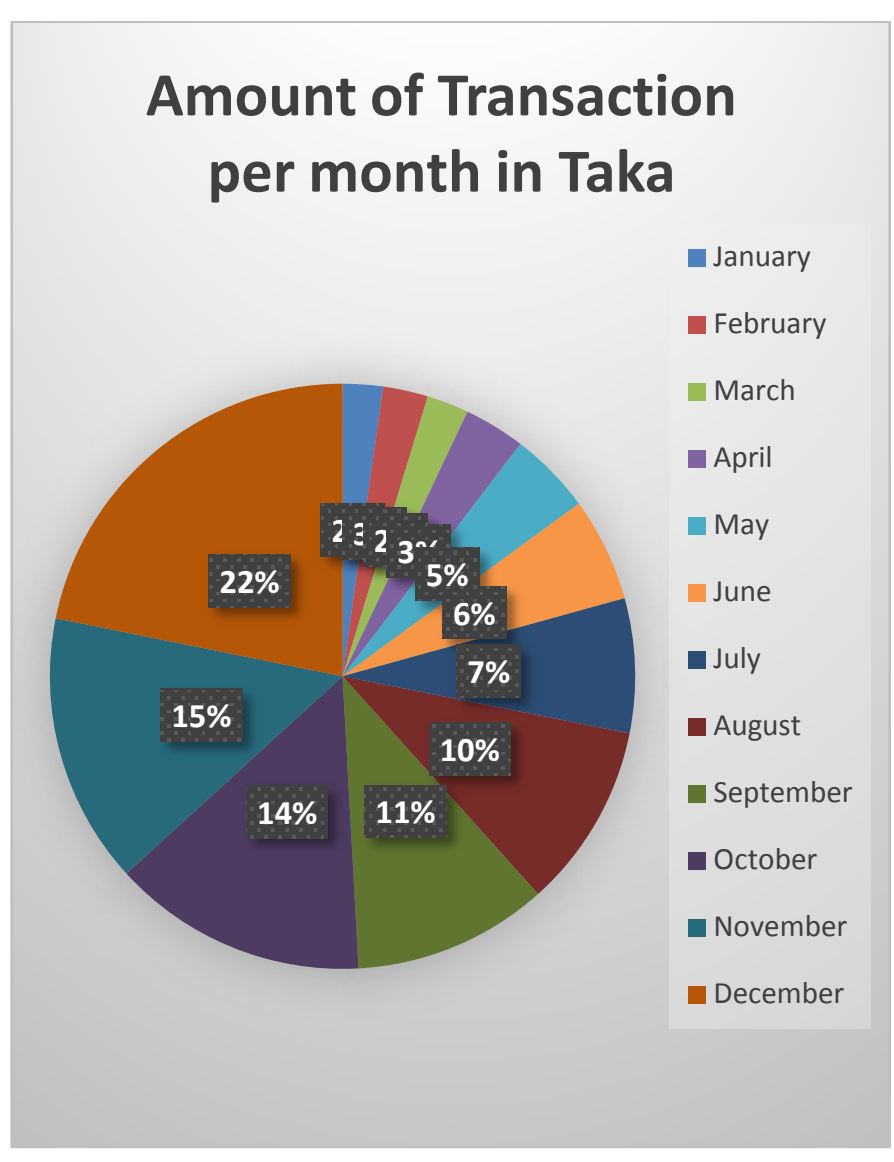

Fig 3: Monthly Transaction Rate in 2018

\section{NATIONAL PAYMENT SWITCH BANGLADESH}

It is an electronic platform enabling inter-bank card based transaction or online retail transactions with the help of Automated Teller Machines, Internet Banking Fund Transfer network or POS machine since its commencement in 2012. NPSB promotes e-commerce facility throughout Bangladesh. According to the financial stability report of Bangladesh Bank, 53 commercial banks are controlling card business. Among them, Internet Banking Fund Transfer network transactions of 19 banks are being routed through NPSB. In November 2018, six banks signed up for the fund transfer facility through the NPSB. They were: Bank Asia, Standard Chartered Bank, Bangladesh Commerce Bank, City Bank, Dutch-Bangla Bank and Midland Bank [8].

In the year of 2018, around 24 million transactions amounting 15500 crore taka had been settled via NPSB. It recorded a growth of $49.18 \%$ and $48.71 \%$ and in terms of amount of 
payments and no. of transactions respectively.

\section{BEFTN}

BEFTN (Bangladesh Electronic Funds Transfer Network) that is operated by Bangladesh Bank plays a key role for the rapid progress of internet banking system. BEFTN settles not only credit transactions but also debit transactions. There are different types of credit transactions such as: foreign and domestic remittances, payroll, social security payments, company bonuses, bill payments, corporate payments, government tax payments and person to person payments etc. There are different types of debit transactions such as transactions utility bill payments, insurance premium payments, EMI payments of a product etc. As a result, paper based instrument is reducing and electronic payment is increasing. In the year 2018, on average, 67956 transactions were established per day through the BEFTN system, and this transaction rate was 33.333 percent higher than that of 2017 . Nearly 1,72,285 crore taka was processed successfully via BEFTN and this trend was 29.2 percent higher than the transaction trends of 2017.

\section{CHALLENGES OF INTERNET BANKING SYSTEM}

Though we have seen some sharp rise in the growth of internet and internet users, there are some impediments on the way to the growth of internet in Bangladesh. Some of the reasons can be illustrated below:

i. Underdeveloped IT industry.

ii. Lack of efficient use of ICT based network.

iii. No direct access to the information super highway.

iv. Limited skilled human resources.

v. Low-level of computer literacy.

vi. Lack of IT professionals who are good at network security.

Bank Accounts and Credit Cards can be considered as the major targets of Cyber threats or attack based on the Symantec Internet Security Threat Report published in JulyDecember 2007. Based on the analysis of state-run Bangladesh e-Government Computer Incident Response Team (BGD e-Gov CIRT) under the Ministry of Posts, Telecommunications and Information Technology, the cyber related attacks registered with the financial and non-financial institution increased to 663 in 2017 from 379 in 2016 [10]. The number of registered cyber related incidents in 2018 was 870.

Of the attacks, vulnerability accounts for 63.2 per cent, intrusion or hackings 5.7 per cent, malicious code 22.5 per cent, abusive content 4.5 and the rest comprise fraudulence, intrusion attempts, service request, information security and others. The biggest fraud incidence in the area of ATM card occurred in February 2016. At the time of that incidence, hackers planted skimming devices in several ATM booths of some commercial banks for the purpose of stealing card information as well as creating duplicates, according to the report of Bangladesh Bank. The Bangladesh bank found that more than two hundred cardholders lost data to the fraud. Of Taka 25 lakhs stolen by the racket, the Eastern Bank Limited lost around Taka 14 lakhs. Nearly 10 million takas was deceived in such incidents which affected City Bank limited, United Commercial Bank limited and Premier Bank limited. City Bank was forced to repay a significant amount to its customers whose cards were swindled. Brac Bank also repaid 0.7 million Tk. to its customers for the same reason in April, 2018. Based on the research of Bangladesh Institute of Bank Management (BIBM), only 38 per cent of existing banks were fully-equipped to fight against cyber-attacks while 28 per cent were totally vulnerable and 34 per cent were partly secured.

There are some of the ramifications explained shortly in this paper. They are:

a) Phishing: It is a process used by fraud people in order to gain sensitive information i.e. user id, passwords and debit or credit card details by pretending to be an email or message from a trustworthy organization. Communications claiming to be from banks, popular social websites are normally used to trick the unsuspecting public.

Phishing that targeted cloud computing services such as Software as a service and internet mail services became the biggest category of phishing. At 36 percent of all phishing attacks, it eclipsed phishing against the payment services category for the first time. The detected phishing sites according to the Anti Phishing working Group (APWG) in first quartile of 2018 was $1,80,768$. The detected phishing sites according to the APWG in third and fourth quartile of 2018 was $1,51,014$ and 1,38,328 respectively. The number of unique phishing reports submitted to APWG during the first quartile of 2019 was $1,12,393$ [12].

b) Malware: It is malicious software that is created by hackers and criminals to infiltrate computers. It is used for a large number of illegal purposes such as stealing personal information, deleting or corrupting data, creating botnets (networks of infected computers) and bypassing security software. There are some malicious software such as Trap door, Trojan Horse, Wanna Cry Decryptor, Virus etc.

c) IP Spoofing: In this attack, attackers send packets to another party with the disguise of the source IP address. It can lead to fake websites.

d) Denial of Service (DoS attack): Network-based attack always could cost a lot for an organization. One of the prominent network-based attacks is the denial of service attack, which can be prevented by using design decision [14]. Financial institutions need to check the vulnerabilities of the network in order to prevent cyber-attack. Application vulnerability assessment, host vulnerability assessment, and security best practices are included in Penetration testing. Penetration testing can be performed with or without the proper knowledge of the working environment $[13,15]$.

e) SQL Injection Attack: It is a vulnerability that results when the attacker is given the ability to influence the structured Query Language Queries that an application passes to a back-end database. The success of the attack is usually highly dependent on the underlying database and interconnected system that are under attack [16].

Considering the challenge and impact on the business, this issue needs to be taken into serious consideration. The ramifications of cyber threats need to be mitigated with higher authority consciousness, trained and skilled people, best process, regular practice and making it as part of regular business.

\section{CONCLUSION}

The advancement of the technology and communication has led to the introduction of a new delivery channel which is internet banking. Internet banking allows customers to 
conduct financial transactions and access to almost any type of banking transaction at the click of a mouse. Bangladesh entered into internet banking quite late and showing a steady progress in this regard as to acceptance and operation of internet banking. This study evaluates internet banking progress with statistical report analysis, problems and prospects in the context of Bangladesh. Security is a very important issue in order to keep internet banking safe and reliable. The attackers tend to target the weakest link. Once the attacker has control over a user's computer, he or she can modify the information flow to his or her advantage. The situation most likely will not change until new transaction methods are introduced. So, whenever using an online financial system today, we have to ensure that our system is still under our control and not a spoofed puppet.

\section{REFERENCES}

[1] Bowman, M., Debray, S. K., and Peterson, L. L. 1993. Reasoning about naming systems. 1. J. R. Chowdhury, "Information Technology in Bangladesh", A paper on IT policy in Bangladesh, April 1999.

[2] L. Press, "Against All Odds, The Internet in Bangladesh", A Report on IT in developing countries, The MOSAIC Group, Fairfax, VA, March 1999.

[3] Md. Mohiuddin, "Trend and Development of E-Banking: A Study on Bangladesh", IOSR Journal of Business and Management (IOSR-JBM), Volume 16, Issue 5, PP 1624, May. 2014

[4] M S Sadekin and A H Shaikh, "Current Status of E-Banking Practices in Bangladesh", Scholar Journal of Business and Social Science, Vol.1, 2015.

[5] Fahmida Huda, Tanvir ahmed Chowdhury, "Prospect of E-Banking in Bangladesh: New way to make banking electronic", Asian Economic and Financial Review, Vol. 7, No.9, pp 509-518, 2017.

[6] Mohammad Shamsus Sadekin, Md. Abdul Hannan Shaikh, "Effect of E-Banking on Banking Sector of Bangladesh", International Journal of Economics, Finance and Management Sciences, Vol. 4, No. 3, 2016, pp. 93-97. doi: 10.11648/j.ijefm.20160403.11
[7] Mohamamd Shamsus Sadekin, Dr. Md. Abdul Hannan Shaikh, "Current Status of E-Banking Practices in Bangladesh", Scholar Journal of Business and Social Science, Volume 1, Issue 1, pp. 53-64, 2015.

[8] AKM Zamir Uddin, "Online fund transfer to any bank from June", Published in The Daily Star, April 19, 2018 https://www.thedailystar.net/business/banking/onlinemoney-transfer-to-any-bangladeshi-bank-account-fromjune- 1564456

[9] Uddin, M. S., M. R. Alam and K. Rabbi, 'IT Operations of Banks', Banking Review Series, BIBM, Dhaka, Bangladesh, 2014.

[10] Farhana Haque Sumi, Lokesh Dutta and Farhana Sarker. "A Review on Cyberattacks and Their Preventive Measures", International Journal of Cyber Research and Education (IJCRE), 1(2), pp. 12-29, 2019 doi:10.4018/IJCRE.2019070102

[11] The APWG Phishing Activity Trends Report: https://www.thedailystar.net/frontpage/foreigners-atmfraud-ring-511822, Published May 15, 2019.

[12] ] "Phishing activity trends report 1st quarter 2019". https://docs.apwg.org/reports/apwg trends_report_q1_20 19.pdf

[13] T. Peng, C. Leckie, and K. Ramamohanarao, "Survey of network-based defense mechanisms countering the dos and ddos problems", ACM Computing Surveys (CSUR), vol. 39 , no. 1 , p. 3,2007

[14] B. Arkin, S. Stender, and G. McGraw, "Software penetration testing", IEEE Security \& Privacy, vol. 3, no. 1, pp. 84-87, 2005

[15] Hamad AL-Mohannadi, Irfan Awan, Jassim Al Hamar, Yousef Al Hamar, Mohammad Shah, Ahmad Musa, "Understanding Awareness of Cyber Security Threat among IT Employees", 6th International Conference on Future Internet of Things and Cloud Workshops, pp. 188-192, 2018

[16] Justin Clarke, "SQL Injection Attacks and Defense", Page 1-7, Elsevier Publisher, 2012. 